RICHARD SAKWA, Professor of Russian and European Politics, School of Politics and International

Relations, University of Kent, Canterbury CT2 7NX, UK. Email: $\underline{\text { R.Sakwa@kent.ac.uk }}$

Richard Sakwa (2018) One Europe or None? Monism, Involution and Relations with Russia, Europe-Asia

Studies, 70:10, 1656-1667, DOI: $\underline{10.1080 / 09668136.2018 .1543762}$

\title{
One Europe or None? Monism, Involution and Relations with \\ Russia
}

\section{RICHARD SAKWA}

IN 2014 THE QUARTER-CENTURY OF THE COLD PEACE FROM 1989 came to an end, and the continent was forced to come to terms with the harsh reality that the idealism and aspirations vested in the fall of the Berlin Wall and the destruction of the 'Iron Curtain' had not been fulfilled. Instead of the creation of a 'common European home', as advanced by the last Soviet leader, Mikhail Gorbachev, in Strasburg in July 1989, or the alternative but putatively complementary vision of one Europe 'whole and free', as articulated in the 'Charter of Paris for a New Europe' (OSCE 1990), the continent was once again divided. In fact, the roots of the later breakdown lie in the contrasting ideological projects embedded in these two formulations. On the one hand, although Gorbachev admitted that he was uncertain about the new 'architecture of our "common home", he insisted that it would have many rooms (Gorbachev 1989). His model suggested a pluralistic Europe of diverse social systems and state orders coexisting peacefully, united in what was later formulated as the 'greater Europe' idea of some sort of pan-continental community stretching from Lisbon to Vladivostok.

The idea was not unique to Russia and has been expressed in various forms by European thinkers and leaders over the years, but its elucidation could have become the great European project of the late twentieth century. This is a dialogical model of post-Cold War politics based on a transformative agenda, in which all parties change as a result of the end not only of the Cold War but also of the underlying strategic 
contestation between East and West and of the ideological conflict between capitalist democracy and revolutionary socialism. By contrast, the ideology underlying 'Europe whole and free' became clear only later, and entailed not transformation but a logic of enlargement: initially of a normative sphere, but later reinforced by the physical enlargement of the Atlantic community as instantiated by the European Union (EU) and the North Atlantic Treaty Organization (NATO) (Sakwa 2017a). This was part of the broader failure to achieve a transformation of post-Cold War world order, with Russia once again becoming the 'other' to the Atlantic system and the US-led liberal international order. With the perceived failure of the aspirations vested in greater Europe, which from Moscow's perspective would have required the 'panEuropeanisation' of strategic security issues accompanied by the emergence of Europe as an independent actor on the world stage, Russia from 2012 took the lead in creating the sinews of a 'post-Western' world order (Stuenkel 2016).

This commentary takes an interpretive look at how Europe once again became divided, and how the unique historical opportunity to transform European international relations at the end of the Cold War was lost. It also notes that the historical situation has once again become increasingly fluid, and the nearly three-decades-long stasis following the Cold War is now being broken by the confluence of many factors, including the election of a radical mercantilist to the White House in November 2016. In response to the unilateralism of President Donald J. Trump, European leaders such Angela Merkel in Germany and Emmanuel Macron in France are now calling for greater European 'strategic autonomy', in the words of the EU's Global Strategy (EUGS) (European Union 2016), adopted by the European Council on 28 June 2016. We are once again entering a liminal period, of the sort that appears to shape the destiny of Europe once a generation. The erosion of accustomed patterns of Atlantic solidarity in recent years provides an opportunity for institutional development and ideational innovation in Europe, although the weakening of the normative bonds of post-Cold War community signals the return of some old problems.

\section{Monism and enlargement}

The Russian narrative argues that at the end of the Cold War the country was once again left out in the cold. The idea of 'greater Europe' for Moscow represented a mechanism to achieve pan-European integration and reconciliation. Instead of mutual transformation, all that appeared to be on offer was the 
unmediated enlargement of an already constituted 'historical West'. Whatever its virtues, the expansion of a normative and security order did not resolve the problem of Russian territoriality, and indeed appeared to threaten the country's domestic coherence and its foreign policy standing (Tsygankov 2014). By 2014 it was clear, despite efforts to soften the exclusion, that there was no way for Russia to be assimilated into the existing structures of Euro-Atlantic security. Russia was too big, too independent, too proud and ultimately too strong to become part of an expanded historical West. Russia's geopolitical concerns and sense of itself as a great power meant that it could not easily be subsumed into the Atlantic West. In the early post-Cold War years, Russia was ready to adapt to the exigencies of the world order represented by the Atlantic community, but in the end the adaptation demands proved too high. In particular, the Russian elite resisted ‘Europeanisation' when it was defined as conforming to EU conditionality (Kratochvíl 2008).

Russia nevertheless continued to defend a more pluralistic type of Europeanisation, just as it sought the transformation of the historical West into a greater West, a community transformed by the presence of Russia's vast civilisational, strategic and material potential. The reluctance of the West to accept such a transformation is understandable, given that all that was on immediate offer was an economically devastated country with grave governance problems. These problems were recognised by the more enlightened part of the Russian leadership, but they insisted that they would deal with them in their own time and in their own way (Surkov 2010). The transformative power of Europeanisation through conditionality had reached its limits (Grabbe 2006). The difference between the two logics of integrationtransformation versus enlargement - in the end led to estrangement. Russia increasingly felt trapped in a strategic impasse in which it could neither join NATO nor the EU, yet its own space for sovereign development and great power interests were stymied. The quarter-century of the cold peace gave way to resistance and conflict.

This is where the concept of monism can help to elucidate the underlying structural basis to the renewed contestation between Russia and the Atlantic West. Monism is the classic metaphysical view in philosophy that there is only one basic substance or principle as the basis of reality. It is usually contrasted with dualism or pluralism. In history monism means that there is one overriding causal factor that determines behaviour. Here the term is applied in a rather more limited manner, meaning the view that history tends in one direction to create a singular form of political modernity. Paul Grenier frames the issue 
in the form of a puzzle: 'why liberal modernity can't live with any principle of order other than itself' (Grenier 2015). In practical terms in the post-Cold War era, this means the merger of geopolitics and democratisation into a single expansive power system (Sakwa 2017a, pp. 98-104). Olga Baysha argues, on the basis of a study of social movements in the late Soviet period, Euromaidan and the White Ribbon movement in Russia that "the "progressive" imaginary, which envisages progress in the unidirectional terms of catching up with the "more advanced" Western condition, is inherently anti-democratic and deeply antagonistic' (Baysha,2019, p. xi), The corollary is that societies or states that resist are deviant in one way or another, and will sooner or later suffer the consequences. Democratic peace theory and various models of democracy promotion are manifestations of a fundamentally monist appreciation of international affairs. The unifying principle is not that of the 'common good', but of the adaptation (and ultimately subordination) of the outsider to the norms and power conventions of the enlarging order. The 'diabolical' (divisive) character of liberal modernity is not transcended, but instead suppressed through neo-imperial enlargement (Schindler 2017).

In contemporary Europe the philosophical character of political monism is harnessed to an expansive geopolitical dynamic in which the monadic power system reinforces an increasingly singular model of development. Normative power is itself a form of hegemony (Diez 2013). The monist moment is redefining the West itself, which in the regional context means the Atlantic community and its allies (Browning \& Lehti 2010). The failure to establish a greater West means that everything outside the old West becomes problematic. The very notion of 'subaltern' introduces hierarchy into a relationship that the greater Europe model of post-Cold War order suggests is structurally equal (Morozov 2015). The recalcitrant states, above all Russia, responded by devising new patterns of resistance. In a classically paradoxical manner, monism gives rise to new forms of pluralism. However, accustomed forms of diplomacy do not operate as they once did in this new form of contestation between an enlarging monist system and the defenders of a pluralistic international order who fail to formulate a normatively attractive alternative other than the principle of pluralism itself. Relations between the EU and Russia became didactic and historicist (Prozorov 2016), assuming that the solutions devised in Western Europe were applicable to a country with intense security concerns and a very different historical experience. This is why the current, Second Cold War is far more dangerous than the first (cf. Cohen 2018; Legvold 2016). In 
the first Cold War, two readily comprehensible and historically rooted conceptions of progress and international politics - capitalist democracy and revolutionary socialism-battled it out; in the second, there is no common ontological perception of reality to structure interactions nor are there any customary practices to regulate the conflict.

Contemporary European monism is rooted in a number of processes, here presented schematically. First, the way that the Cold War ended allowed ultimately the imposition of a triumphal 'victory' discourse on what had been assumed by the Soviet and, later, the Russian side to be a common victory. The turning point was the Malta Summit of December 1989, at which the Soviet and US leaders decided the fate of Europe. The absence of a West European leader is indicative of the way that Europe failed to gain a substantive independent political subjectivity in the post-Cold War years. As at Yalta nearly half a century earlier, the great powers held the fate of Europe in their hands, but Malta registered the change in the diplomatic and strategic balance of power. The Soviet side hoped to register politics of positive transcendence, based on the idea that the end of the Cold War was a common victory that would allow a new era of cooperative politics (Cohen 2009; Matlock 1995, 2004, 2010). Gorbachev, as we have seen, sought a new European order that would be geopolitically multipolar and ideationally plural. Instead of a positive transcendence of the Cold War, in practice a negative version was achieved that simply registered a power shift rather than a transformation in the nature of power in Europe (Itzkowiz-Shifrinson 2013). The potential for combining multiplicity with unity was lost (Biebuyck \& Rumford 2012). The absence of an overarching mode of European integration provoked the clash of two partial projects, precipitating the renewed division of the continent.

Second, the Helsinki Final Act of August 1975 eventually elevated human rights to the centre of European international politics. Helsinki confirmed Yalta, above all, the borders established in 1945 and the framework for the conduct of relations between the great powers, but at the same time Helsinki's 'third basket' of human rights commitments provided a mechanism for the transcendence of Yalta. The Malta agreements built on the Helsinki Final Act and were codified in the Charter of Paris. Helsinki established a particular method for Yalta's transcendence, which itself ultimately proved corrosive of post-Cold War international order. This was a values-based agenda, which provided a powerful platform for East European dissidents to critique their own government when they failed to uphold the principles to which they had 
agreed. These were values to which both Gorbachev and Boris Yel'tsin were committed, but the framework for their advancement in the post-Cold War years became monist rather than pluralist, sustaining a mode of discourse that tended to delegitimate the political subjectivity of the interlocutor (Geis 2013). Human rights became part of the substantive discourse in relations between states, displacing more traditional forms of diplomacy. Democracy promotion and 'colour revolutions' may well be responses to modernisation challenges, but when embedded as part of an expansive power system they are inevitably subsumed into the reproduced zero-sum logic of Cold War politics in which 'everyone loses' (Charap \& Colton 2016). As realists have long argued, the struggle for democracy and human rights does not stand outside power relations. Pragmatic US leadership 'transformed into a much more uncompromising mindset of missionary zeal' (Mazarr \& Koffman 2018, p. 107). The contradiction between ends and means discredited the whole process and normal diplomatic intercourse between nations was distorted by normative agendas (Geuss 2008).

The third factor shaping the monism of the cold peace and its ultimate degeneration into renewed confrontation is the failure of Europe to assume an independent political subjectivity. In the postcommunist era there was much talk of the EU as a postmodern polity in which rules, regulations and norms take precedence over diplomacy, power and coercion (Ruggie 1993). This can be couched otherwise in terms of a tension between the horizons of time and space, in which the reconfiguration of territory reshapes political identities (Borg \& Diez 2016). This has been taken further in suggesting a sharp division between the EU's postmodernity and the recalcitrant outsiders who remain locked in modernist ways of thinking (Cooper 1998, 2003). While the logic of norm diffusion operates for the former, the language of power and coercion is exercised against the latter. This is precisely the problem of involution (see below). The EU's civilian power is embedded in a larger Atlantic security system, in which traditional practices of security politics still reign supreme. The EU turned out to be the velvet glove over the mailed fist of the Atlantic power system (Mearsheimer 2014). This duality only intensified Russia's strategic impasse, since engaging with the EU is not necessarily the same as that needed to engage with NATO.

Fourth, the monism of the Atlantic system is diverse in form. From Moscow's perspective, the Atlantic community talks in two discursive registers: first, the EU's post-Westphalian discourse of sovereignty-dilution and, second, NATO's narrative of traditional hard security issues, although this, too, is 
typically couched in the language of norms and values. Understandably, it is hard to establish a stable relationship with such a hydra-headed entity. Discourse shifts from power to values, interests to norms, in an endlessly protean manner. It is not clear how dialogue can be maintained with a community that simultaneously speaks the language of liberal internationalism and coercive hegemony. The very notion of 'spheres of influence' has been delegitimated, while the 'liberal international order' acts as if the world is an extended arena for its universalistic ethos. The Monroe doctrine is effectively limitless, and the universal sphere of influence appears intolerant of those beyond. In the 1990s the EU embarked on a 'civilising mission' to tame its wild eastern marches (Zielonka 2013). This monist and expansive Atlantic system (what in the original Cold War was known as 'the West') was endowed with some of the characteristics of earlier imperial systems analysed by postcolonial thinkers, in which others are assigned to the waiting room of history until called into the sunlit uplands of Western modernity (Chakrabarty 2000).

The response in Russia has been to emphasise its civilisational specificity (Maslovskiy 2016). Russia once again presents itself as the champion of the 'true' Europe against the 'false' Europe locked in Atlantic structures (Neumann 2016). Specifically, although Gorbachev's concept of the common European home was vague on details, the fundamental argument is clear: 'What we have in mind is a restructuring of the international order existing in Europe that would put the European common values in the forefront and make it possible to replace the traditional balance of forces with a balance of interests' (Gorbachev 1989). The interests at stake were those of the sovereign states making up Europe, now united in their diversity but committed to the creation of a new political community. Greater Europe was a programme for geopolitical and normative pluralism while avoiding a return to the balance of power politics that had kept the continent in thrall for so long (Gromyko \& Fëdorova 2014). Gorbachev eloquently and forcefully argued that different systems could coexist peacefully. In his Council of Europe speech and later, Gorbachev called for the transcendence of both Yalta and Malta. He sought to create a new type of European international relations that encompassed the interests of both the small and great powers (Gorbachev \& Ikeda 2005). This was to be a multipolar Europe with room for experimentation and diversity, representing a space in the greater West in which Russia would be a co-founder of a new and more cooperative political order.

Instead, the EU effectively claimed to be the sole legitimate voice of Europe, although in partnership with the more specialised Council of Europe and the Organization for Security and Co- 
operation in Europe (OSCE). This is the 'smaller Europe' project, embedded in the broader Atlantic community (Gromyko 2015). This monist vision of Europe, until recently, had been unable to imagine any substantive alternative political, let alone ideational, community. Just as liberalism in the post-Cold War era finds it hard to accept alternatives to its own hegemony and thus erodes its own liberality, so the smaller Europe (and the Atlantic community of which it is part) has not been able to find an appropriate form of engagement with outsiders. It was assumed that the solutions to the problem of history in one context are universally applicable to others. Even if a leadership in Russia were to accept this inverted neo-Marxist theoretical postulate (as it did to a large extent in the Yel'tsin years), the fact that historical problems of territorial unity, political identity, security cooperation, economic modernisation and international integration have still not been resolved means that tensions, if not conflict, will inevitably arise. Historicism, of both the Marxist and the liberal variants, ultimately break against what Chebankova calls Russia's 'paradigmatic pluralism' (Chebankova 2017). The complex multi-faceted civilisational entity that we call Russia that survives through maintaining its autonomy, although it degrades when this autonomy is not adequately accompanied by internal openness and external integration. The strategic impasse in which Russia perceived itself to be trapped for a quarter of a century meant that sooner or later it would try to break out, and in doing so try to find allies and to endow the endeavour with some sort of ideational mission.

\section{Involution and stasis}

The argument presented here suggests that the root cause of the Second Cold War is the failure to provide an institutional or ideational framework for a continental vision of Europe (Zwolski 2016). The 'little Europe' represented by the EU claimed a normative and geographical superiority—as the embodiment of the ideals and aspirations of Europe 'whole and free' (Crouch \& Marquand 1992, p. 1). These claims were in part justified, since the EU represents a coherent and rational response to the problems of Europe: its fragmentation, repeated wars and enduring conflicts, and uneven development. The EU certainly did not solve these problems, and the distortions of the eurozone have even exacerbated them, yet the EU represents one of the most successful attempts of non-imperial regional integration in human history. As a peace project it has been spectacularly successful in the western part of the continent; paradoxically, 
however, this very success has undermined its ability to achieve the same result on a continental scale. The EU remains at heart a functionalist enterprise, dominated by a technocratic rationality and a bureaucratic mentality. This 'rules-based' order is the crowning achievement of European integration, substituting the sword with the pen, but the conditionality-driven logic of enlargement in the post-Cold War era proved inadequate when it came to Russia (Maas 2016).

The ideational foundations of Russia's hopes for structural transformation may have been illjudged, but in the early period they drew on a common normative framework. However, two different logics of integration came into conflict: technocratic enlargement versus institutional transformation. No common and shared mode of integration could be found, and in the end the two sides drifted apart and then became deeply estranged (Forsberg \& Haukkala 2016). These competing rationalities (Averre 2009) proved catastrophic when it came to competition in what became known as the 'shared neighbourhood'. The term itself already suggests the logic of conflict in which the countries 'in between' are forced to choose. The Ukraine conflict is the child of the cold peace and the monist pattern of politics on which it is based (Sakwa 2017b). Instead of some sort of renegotiated settlement of the European peace order after 1989, the logic of enlarging existing institutions became the predominant mode of engagement. After 1989, the 'victors' at the end of the Cold War, fearing institutional weakening and normative dilution, sought to consolidate their victory not through transformation but through enlargement. This meant that the EU was unable to escape the conditions of its birth, and remained trapped in the Atlanticist carapace. This foreclosed the EU's development as a separate pole in global politics and stunted its ability to become part of a greater European continental agenda of peace and reconciliation.

This is what in this paper is called 'involution'. In the biological sciences involution occurs when something turns in on itself or when an organism is reduced in size, and effectively means the opposite of evolution. The term has been applied to help explain the Soviet collapse (Derluguian 2000) and to analyse the shrinkage of the Russian economy in the 1990s. Burawoy (1996) argued that the Russian economy eroded its own foundations by diverting resources from production to exchange. In the case of the EU, the involution has been a twofold process. First, in the 1990s the question was posed in terms of 'widening' or 'deepening', and in the end there was significant development on both, but the putative third leg was missing - the transformation of post-Cold War European community and the Europeanisation (not just EU- 
isation) of continental politics. Successive waves of enlargements brought total membership of the EU to 28 (27 when the UK leaves) and the various treaties, from Maastricht in 1992 to Lisbon in 2009, extended the institutional ramifications of the EU. However, despite the spatial extension and institutional changes, including the creation of the European External Action Service, no European 'super-state' has been created (except in the imagination of Brexiteers). Second, despite the introduction of a Common Foreign and Security Policy (CFSP), security and defence remain largely national priorities, and moves to extend the EU's competencies have been resisted. In the post-Cold War era, the EU has become more deeply embedded as one of the wings of the Atlantic system, and attempts to create an independent defence force or articulate a sustained independent European foreign policy have been stymied by fears that this would play into the hands of Moscow. This is not to say that there have not been distinctive EU policies on important issues, such as Palestine and Iran, but overall until the great Trumpian disruption, elements of Cold War bloc discipline continued to be exercised.

The transformation of European international relations was stymied, and the predominance of the enlargement agenda in the end had two consequences. First, the Atlantic project was radicalised, in both ideological and political terms. The 'unipolar' moment of US hegemony, as termed by Charles Krauthammer (1991), was accompanied by the continuation of what during the Cold War had been called superpower 'overlay' over the western part of the continent. This was certainly comforting to the former Soviet bloc countries, who could now shelter under the US umbrella. However, this only perpetuated Cold War patterns and attitudes, and did nothing to advance the project of European unity (Parker 2019). Second, the EU remained trapped in the matrix in which it had been born. The EU was a child of the Atlantic system and had been nurtured within the framework of the Cold War contest with the Soviet Union (Laughland 1998). After 1989 Moscow anticipated that the EU would become the core of a new settlement in which superpower overlay would be a thing of the past, and Europe could finally gain a subjectivity and political voice of its own. Russia very much wanted to be part of this new order. The initial option was for 'little Europe' to become a wider Europe encompassing in one way or another Russia, possibly through some sort of 'strategic alliance' (Bordachev 2009). Later, the 'greater Europe' agenda predominated, a plural Europe of the EU, Russia, Turkey, Ukraine and other countries coming together to create some sort of 'union of Europe' (Karaganov \& Bordachev 2009, 2010). In the event, neither was achieved, and instead 
Atlanticism not only survived but was radicalised, with Russia once again thrown back onto its Eurasian heartland.

The negative transcendence of the Cold War, in which a power shift was recognised but no transformation of European politics was achieved, allowed Cold War institutions and ideology to flourish, providing a fertile breeding ground for resentments, exclusions and renewed conflict (Sakwa 2013). Russia's encouragement of EU autonomy from the United States was seen as an attempt to drive a 'wedge' between the two wings of the Atlantic alliance, stultifying pan-continental unification. Equally, trapped in its Atlantic cocoon, EU development gave way to involution, in which, rather than acting as the solution to historical problems of peace and reconciliation on the continent, it became no more than an instrument for the perpetuation and even exacerbation of traditional European divisions. In part this derived from the intensification of monist representation of the EU. Locked in a power system dominated by the world's only surviving superpower, Atlanticism inevitably assumed features of the unipolarity of which it was part. Monism is the ideological consequence of the logic of expansion. EU enlargement was accompanied by the formulation of the normative and technical conditions required for membership, accompanied by a unidirectional process of change in accession countries. The didactic elements were accentuated, and dialogue and negotiation were thereby attenuated.

\section{Conclusion}

The predominance of a single model of normative behaviour that was considered universal was bound up with a power system that was unprecedented in its scope and ambition to transform the world. The issue here is not whether the US-led liberal international order has delivered positive public goods, because clearly it has, but on what terms this order engaged with outsiders (Ikenberry 2011). In the case of Russia, the normative aspirations of the 1990s coincided with those of the Atlantic system, but its power, status and security considerations did not, a gulf that in the Putin years has widened considerably. The price for Russia of adapting to the existing power and normative system, in terms of status, autonomy, security and sovereignty, was in the end considered too high. Instead, Russia increasingly advanced the structural pluralism associated with the notion of multipolarity (Smith 2013), while also defending the principle of systemic diversity. Moscow’s critics point out the inconsistency between Russia's defence of pluralism 
abroad while imposing a monistic system of governance at home. In response, Russia has reiterated the realist view that foreign policy is largely independent of the structure of domestic politics, while liberals at home and abroad insist on the close connection (McFaul 2018).

Europe is once again divided, with a new 'iron curtain' gradually being fortified in a line from Narva on the Baltic to Mariupol on the Sea of Azov. A divided Europe is in danger of becoming an absence of Europe in international politics. Having failed to unify, it remains in danger of losing its place on the world stage completely. Europe as a political project has lost autonomous subjectivity, and traditional great powers once again predominate in the international system. The monist vision of a normatively and spatially enlarging Atlantic Europe and the failure to reconcile the two models of European development advanced at the end of the First Cold War provoked the second. Fear of marginalisation prompted the idea of 'strategic autonomy' in the EU's Global Strategy in 2016. The election of Trump in November of that year and his open hostility to the EU, accompanied by suggestions that NATO was 'obsolete', may, paradoxically, end the period of institutional and ideational involution and allow a new evolutionary 'Gaullist' impulse for the European Union, once the current period of enlargement and deepening fatigue is overcome (Haine 2015, p. 991). The involution of Europe has entailed paralysis for the continent as a whole. The many Europes are diminished by the failure to articulate and institutionalise a common European vision for the continent from Lisbon to Vladivostok. Today the long period of institutional and ideational stasis following the end of the first Cold War is beginning to thaw, opening up the renewed possibility of embedding 'one Europe' in new forms of political community.

\section{References}

Averre, D. (2009) 'Competing Rationalities: Russia, the EU and the "Shared Neighbourhood", EuropeAsia Studies, 61, 10.

Baysha, O. (2019) Miscommunicating Social Change: Lessons from Russia and Ukraine (Lanham, MD, Lexington Books).

Biebuyck, W. \& Rumford, C. (2012) 'Many Europes: Rethinking Multiplicity’, European Journal of Social Theory, 15, 1 . 
Bordachev, T. (2009) Novyi strategicheskii soyuz. Rossiya $i$ evropa pered vyzovami XXI veka: vozmozhnosti 'bol'shoi sdelki' (Moscow, Evropa).

Borg, S. \& Diez, T. (2016) 'Postmodern EU? Integration Between Alternative Horizons and Territorial Angst', JCMS: Journal of Common Market Studies, 54, 1.

Browning, C. S. \& Lehti, M. (eds) (2010) The Struggle for the West: A Divided and Contested Legacy (London \& New York, NY, Routledge).

Burawoy, M. (1996) 'The State and Economic Involution: Russia Through a China Lens', World Development, 24, 6.

Chakrabarty, D. (2000) Provincializing Europe. Postcolonial Thought and Historical Difference (Princeton, NJ, Princeton University Press).

Charap, S. \& Colton, T. (2016) Everyone Loses. The Ukraine Crisis and the Ruinous Contest for PostSoviet Eurasia (London, Routledge/Adelphi).

Chebankova, E. (2017) 'Ideas, Ideology and Intellectuals in Search of Russia's Political Future', Daedalus, $146,2$.

Cohen, S. F. (2009) Soviet Fates and Lost Alternatives. From Stalinism to the New Cold War (New York, NY, Columbia University Press).

Cohen, S. F. (2018) Why Cold War Again? How America Lost Post-Soviet Russia (London and New York, NY, I. B. Tauris).

Cooper, R. (1998) The Postmodern State and the World Order (London, Demos).

Cooper, R. (2003) The Breaking of Nations. Order and Chaos in the Twenty-First Century (New York, NY, Atlantic Monthly Press).

Crouch, C. \& Marquand, D. (1992) 'Introduction', in Crouch, C. \& Marquand, D. (eds) Towards a Greater Europe? A Continent without an Iron Curtain (Oxford, Blackwell).

Derluguian, G. M. (2000) 'The Process and the Prospects of Soviet Collapse: Bankruptcy, Segmentation, Involution', in Derluguian, G. M. \& Greer, S. L. (eds) Questioning Geopolitics. Political Projects in a Changing World-System (Westport, CT, Greenwood Press).

Diez, T. (2013) 'Normative Power as Hegemony', Cooperation and Conflict, 48, 2. 
European Union (2016) "“Shared Vision, Common Action: A Stronger Europe”. A Global Strategy for the European Union's Foreign and Security Policy', June 2016, available at: https://europa.eu/globalstrategy/en/global-strategy-foreign-and-security-policy-european-union, accessed 24 October 2018.

Forsberg, T. \& Haukkala, H. (2016) The European Union and Russia (London, Palgrave).

Geis, A. (2013) “The Concert of Democracies": Why Some States are More Equal than Others', International Politics, 50, 2.

Geuss, R. (2008) Philosophy and Real Politics (Princeton, NJ \& Oxford, Princeton University Press).

Gorbachev, G. (1989) 'Europe as a Common Home', Address to the Council of Europe, Strasbourg, 6 July, available at: http://polsci.colorado.edu/sites/default/files/1A Gorbachev.pdf, accessed 11 January 2016.

Gorbachev, M. \& Ikeda, D. (2005) Moral Lessons of the Twentieth Century. Gorbachev and Ikeda on Buddhism and Communism (London, I. B. Tauris).

Grabbe, H. (2006) The EU's Transformative Power. Europeanization through Conditionality in Central and Eastern Europe (Basingstoke, Palgrave Macmillan).

Grenier, P. (2015) 'Why Liberal Modernity Can't Live with any Principle of Order other than Itself: A Study in Geo-political Philosophy', unpublished paper delivered to the Institute of International Relations, National Research Nuclear University MEPhI, Moscow, 27 October.

Gromyko, A. (2015) Russia, the US, and Smaller Europe (the EU): Competition for Leadership in a Polycentric World, Moscow, Institute of Europe, Russian Academy of Sciences Working Paper 14.

Gromyko, A. A. \& Fëdorova, V. P. (eds) (2014) Bol'shaya Evropa: Idei, real'nost', perspektivy (Moscow, Ves' mir).

Haine, J.-Y. (2015) 'A New Gaullist Moment? European Bandwagoning and International Polarity', International Affairs, 91, 5.

Ikenberry, G. J. (2011) Liberal Leviathan: The Origins, Crisis, and Transformation of the American World Order (Princeton, NJ, Princeton University Press).

Itzkowiz-Shifrinson, J. R. (2013) 'The Malta Summit and US-Soviet Relations: Testing the Waters Amidst Stormy Seas. New Insights from American Archives', 26 July, available at: 
http://www.wilsoncenter.org/publication/the-malta-summit-and-us-soviet-relations-testing-thewaters-amidst-stormy-seas, accessed 11 July 2018.

Karaganov, S. \& Bordachev, T. (2009) 'Towards a New Euro-Atlantic Security Architecture. Report of the Russian Experts for the Valdai Discussion Club Conference', November, available at: http://vid1.rian.ru/ig/valdai/European_security_eng.pdf, accessed 11 July 2018.

Karaganov, S. \& Bordachev, T. (2010) 'Towards an Alliance of Europe. Analytical Report by the Russian Group of the Valdai International Discussion Club', September, available at: http://vid1.rian.ru/ig/valdai/Alliance\%20eng.pdf, accessed 11 July 2018.

Kratochvíl, P. (2008) 'The Discursive Resistance to EU-Enticement: The Russian Elite and (the Lack of) Europeanisation', Europe-Asia Studies, 60, 3.

Krauthammer, C. (1991) 'The Unipolar Moment', Foreign Affairs, 70, 1.

Laughland, J. (1998) The Tainted Source. The Undemocratic Origins of the European Idea (London, Sphere).

Legvold, R. (2016) Return to Cold War (Cambridge, Polity).

Maas, A-S. (2016) EU-Russia Relations, 1999-2015. From Courtship to Confrontation (London, Routledge).

Matlock, J. F. (1995) Autopsy on an Empire. The American Ambassador's Account of the Collapse of the Soviet Union (New York, NY, Random House).

Matlock, J. F. (2004) Reagan and Gorbachev. How the Cold War Ended (New York, NY, Random House).

Matlock, J. F. (2010) Super-Power Illusions. How Myths and False Ideologies Led America Astray-and How to Return to Reality (New Haven, CT \& London, Yale University Press).

Maslovskiy, M. (2016) 'The Imperial Dimension of Russian Modernisation: A Multiple Modernities Perspective', Europe-Asia Studies, 68, 1.

Mazarr, M. J. \& Koffman, M. (2018) 'Rediscovering Statecraft in a Changing Post-War Order', Texas National Security Review, 1, 3.

McFaul, M. (2018) From Cold War to Hot Peace. The Inside Story of Russia and America (London, Allen Lane).

Mearsheimer, J. J. (2014) 'Why the Ukraine Crisis is the West's Fault: The Liberal Delusions that Provoked Putin', Foreign Affairs, 93, 5. 
Morozov, V. (2015) Russia's Postcolonial Identity. A Subaltern Empire in a Eurocentric World (London, Palgrave Macmillan).

Neumann, I. B. (2016) Russia and the Idea of Europe. A Study in Identity and International Relations (London, Routledge).

OSCE (1990) 'Charter of Paris for a New Europe', 21 November, available at: http://www.osce.org/node/39516, accessed 10 July 2018.

Parker, D. (2019) US Foreign Policy Towards Russia in the Post-Cold War Era (London, Routledge).

Prozorov, S. (2016) Understanding Conflict between Russia and the EU. The Limits of Integration (Basingstoke, Palgrave Macmillan).

Ruggie, J. (1993) 'Territoriality and Beyond: Problematizing Modernity in International Relations', International Organization, 47, 1.

Sakwa, R. (2013) 'The Cold Peace: Russo-Western Relations as a Mimetic Cold War', Cambridge Review of International Affairs, 26, 1.

Sakwa, R. (2017a) Russia against the Rest. The Post-Cold War Crisis of World Order (Cambridge, Cambridge University Press).

Sakwa, R. (2017b) 'The Ukraine Syndrome and Europe: Between Norms and Space', The Soviet and PostSoviet Review, 44, 1.

Schindler, D. C. (2017) Freedom from Reality. The Diabolical Character of Modern Liberty (Notre Dame, IN, University of Notre Dame Press).

Smith, M. A. (2013) 'Russia and Multipolarity since the End of the Cold War', East European Politics, 29, 1.

Stuenkel, O. (2016) Post-Western World. How Emerging Powers are Remaking Global Order (Cambridge, Polity).

Surkov, V. (2010) Texts (Moscow, 'Europe’ Publishing House).

Tsygankov, A. P. (2014) The Strong State in Russia. Development and Crisis (Oxford, Oxford University Press).

Zielonka, J. (2013) ‘Europe's New Civilizing Missions: The EU's Normative Power Discourse', Journal of Political Ideologies, 18, 1. 
Zwolski, K. (2016) 'Wider Europe, Greater Europe? David Mitrany on European Security Order', JCMS. Journal of Common Market Studies, 55, 3. 